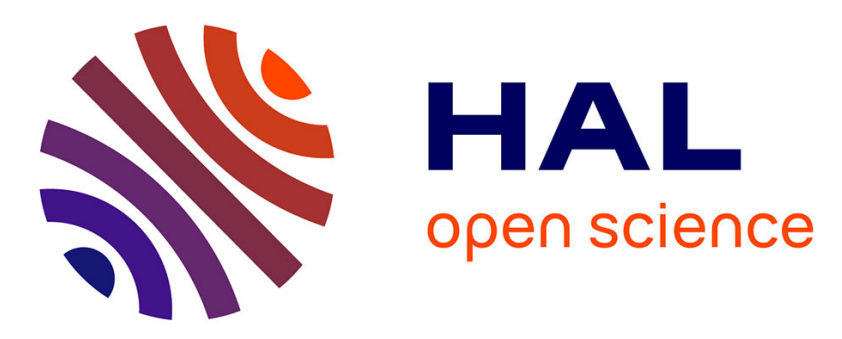

\title{
The effect of starvation on growth and plasma growth hormone concentrations of rainbow trout, Oncorhynchus mykiss
}

\author{
J.P. Sumpter, Pierre-Yves Le Bail, A.D. Pickering, T.G. Pottinger, J.F.
}

Carragher

\section{To cite this version:}

J.P. Sumpter, Pierre-Yves Le Bail, A.D. Pickering, T.G. Pottinger, J.F. Carragher. The effect of starvation on growth and plasma growth hormone concentrations of rainbow trout, Oncorhynchus mykiss. General and Comparative Endocrinology, 1991, 83 (1), pp.94-102. 10.1016/0016-6480(91)90109-J . hal-02713321

\section{HAL Id: hal-02713321 \\ https://hal.inrae.fr/hal-02713321}

Submitted on 1 Jun 2020

HAL is a multi-disciplinary open access archive for the deposit and dissemination of scientific research documents, whether they are published or not. The documents may come from teaching and research institutions in France or abroad, or from public or private research centers.
L'archive ouverte pluridisciplinaire HAL, est destinée au dépôt et à la diffusion de documents scientifiques de niveau recherche, publiés ou non, émanant des établissements d'enseignement et de recherche français ou étrangers, des laboratoires publics ou privés. 


\title{
The Effect of Starvation on Growth and Plasma Growth Hormone Concentrations of Rainbow Trout, Oncorhynchus mykiss
}

\author{
J. P. Sumpter, ${ }^{*}$ P. Y. Le Bail,$\dagger$ A. D. Pickering,$\ddagger$ T. G. Pottinger,$\ddagger$ And \\ J. F. CARragher*
}

*Department of Biology and Biochemistry, Brunel University, Uxbridge, Middlesex UB8 $3 P H$, United Kingdom; †Laboratoire de Physiologie des Poissons, Institut National de la Recherche Agronomique. Campus de Beaulieu, 35042 Rennes Cédex, France; and $¥$ Institute of Freshwater Ecology, Windermere Laboratory, The Ferry House, Far Sawrey, Nr Ambleside, Cumbria LA22 OLP, United Kingdom

Accepted August 2, 1990

\begin{abstract}
Two experiments, one using $0+$ the other $1+$ rainbow trout, were conducted to investigate the effect of prolonged starvation on plasma growth hormone levels. The results from both experiments were essentially the same. As expected, starvation resulted in cessation of growth and in a lower coefficient of condition, whereas fed fish continued to grow and remained in good condition. Starvation had relatively little effect on the plasma cortisol level; in one experiment levels were elevated temporarily in starved fish, although by the end of the experiment there was no longer any difference between starved and fed fish, and in the other experiment plasma cortisol levels remained very low throughout the course of the experiment in both starved and fed fish. In contrast, in both experiments starvation had a pronounced effect on the plasma growth hormone level, which rose steadily during both experiments, such that it was six times higher after 1 month of starvation in $0+$ fish, and five times higher after 6 weeks of starvation in $1+$ fish. Thus, paradoxically, fed fish had very low plasma growth hormone levels and grew rapidly, whereas starved fish had elevated plasma growth hormone levels but did not grow. In both experiments a strong negative correlation was observed between the plasma growth hormone level and the coefficient of condition of the fish. The results are discussed with regard to the well-established metabolic changes that occur during starvation, and it is suggested that a major role of growth hormone during starvation is to aid in the mobilisation of fatty acids and glycerol from adipose stores. (c) 1991 Academic Press. Inc.
\end{abstract}

Many species of fish, including salmonids, undergo periods of reduced food intake as a normal phase of their lives. During such periods of starvation it is necessary to direct energy reserves away from growth and into the support of vital processes. Analyses of both naturally (such as those accompanying migration and/or sexual maturation in many species) and experimentally induced periods of starvation have provided insights into the utilisation of encrgy reserves during starvation. Although it is difficult to generalise, primarily because there may be pronounced species differences (reviewed in Love, 1980), it appears that there are both differential rates of mobilisation of the major body constituents (fat, protein, and carbohydrate), and differential rates of mobilisation of the same constituent from different organs, e.g., fish mobilise more protein from white muscle than from dark muscle. It often appears that there is sequential mobilisation of energy reserves. Many studies report that, besides any changes in carbohydrate stores (whose mobilisation is extremely difficult to measure-see Love, 1980), the first effect of starvation is the mobilisation of lipids (reviewed by Love, 1980; Weatherley and Gill, 1987). The general tendency appears 
to be to conserve body protein at the expense of stored lipid (e.g., Ince and Thorpe, 1976; Weatherley and Gill, 1981).

The control processes underlying the mobilisation of energy reserves during periods of starvation appear quite complex and at present are poorly understood. Hormones are considered to play pivotal roles, and a wide variety of them have been implicated in regulating energy utilisation during starvation. Catecholamines, thyroid hormones, corticosteroids, sex steroids, insulin, glucagon, growth hormone, and prolactin have all been shown to affect protein, carbohydrate, and lipid metabolism in vertebrates, including fish (for effects on fish see Barrett and McKeown, 1988; Higgs and Eales, 1978; Ince and Thorpe, 1976; Plisetskaya, 1985; Plisetskaya et al., 1989; Sheridan, 1986, 1988, and references therein).

In the study reported here we have starved rainbow trout for prolonged periods and used a highly sensitive RIA for growth hormone (Le Bail et al., 1991) to assess the impact of this treatment on blood growth hormone levels in an attempt to link the well-established alterations in metabolism with any concurrent changes in the plasma growth hormone level.

\section{MATERIALS AND METHODS}

Maintenance of experimental fish. This investigation consisted of two separate experiments on hatchery-reared rainbow trout carried out at the Institute of Freshwater Ecology's Windermere hatchery during 1987. All the fish were rearcd in large (1500 liter), outdoor, fibreglass tanks each supplied with a constant flow of Windermere lake water ( 35 liters $\mathrm{min}^{-1}$ ). Fish were fed once daily with commercial trout pellets at the rates recommended by the manufacturers (exact rate dependent upon fish size and water temperature). Oxygen levels in each tank were maintained close to saturation throughout the study. The water temperature varied between 12.1 and $16.5^{\circ}$ in Experiment 1 and 11.5 and $16.5^{\circ}$ in Experiment 2.

Blood sampling. At each sampling time fish were anaesthetized rapidly in phenoxyethanol $(1: 2000)$ and blood samples obtained from the caudal vessels by means of heparinized syringes; with two operators the whole procedure normally took less than $2 \mathrm{~min}$. Following centrifugation at $4^{\circ}$, plasma samples were stored at $-70^{\circ}$ until assayed for growth hormone and cortisol. After blood sampling, each fish was then killed by a blow to the head, weighed, measured (fork length), and sexed.

Radioimmunoassays (RIAs). Both cortisol and growth hormone were measured using established, well-validated RIAs; plasma cortisol levels were determined according to Pickering et al. (1987) and plasma growth hormone levels according to Le Bail et al. (1991).

Statistical analyses. For each experiment, body weight, length, coefficient of condition (condition factor, $K$ factor), plasma cortisol concentration, and plasma growth hormone concentration were separately analysed by analysis of variance (ANOVA, Genstat) with treatment (starved, fed), time, and number (sequence within each sample) as factors. Tanks and fish were used as blocking effects to produce a nested error structure with which to assess the significance of the factors and their interactions. From a plot of residuals against fitted values, appropriate transformations were selected, where necessary, to improve homogeneity of variance. Levels of significance given in this report are derived from these analyses but, for ease of presentation, data are given as arithmetic means \pm SEM. Linear regression was used to correlate $\log _{e}$ plasma growth hormone levels with the coefficient of condition of the fish.

Experiment 1: The effect of starvation on $1+$ rainbow trout. Five hundred and sixty $1+$ rainbow trout (i.e., fish in their second year of growth, Butley strain, mean body weight $295 \mathrm{~g}$ ) were distributed into four outdoor rearing tanks (see above for details) so that each tank contained 140 fish. The fish were left for a period of 2 weeks to recover from the effects of handling stress (see Pickering et al., 1987) and then 10 fish were sampled from each tank ( $0 \mathrm{hr}$ sample). Food was then withdrawn from two of the four tanks (starved group) and further samples of 10 fish per tank were taken at 1,2,4, and 6 weeks. During the course of this experiment, the water temperature varied between 12.1 and $16.5^{\circ}$.

Experiment 2: The effects of starvation on $0+$ rainbow trout. A sample of $12 \mathrm{fish}(0 \mathrm{hr}$ sample) was taken from each of four outdoor rearing tanks each containing $10000+$ rainbow trout (Stirling strain, mean body weight $25 \mathrm{~g}$ ). Food was then withheld from two of the tanks and the remaining two tanks received food, once daily, at the recommended level. At 1, 2, and 4 weeks, a further 12 fish were sampled from each of the four rearing tanks. The limited volume of blood obtained from each fish made it necessary to pool samples from groups of 4 fish, thus giving six pooled plasma samples per treatment at each of the sampling times (three pooled samples from each of two duplicate tanks). 


\section{RESULTS}

\section{Experiment 1: The Effects of Starvation on $1+$ Rainbow Trout}

Marked individual variation in size at each sampling time masked any effect of starvation on body weight until 6 weeks after food withdrawal, when the starved fish had a significantly $(P<0.05)$ lower body weight than the fed fish (Fig. 1a). This difference in mean weight at 6 weeks was not accompanied by any difference in body length (Fig. 1b).
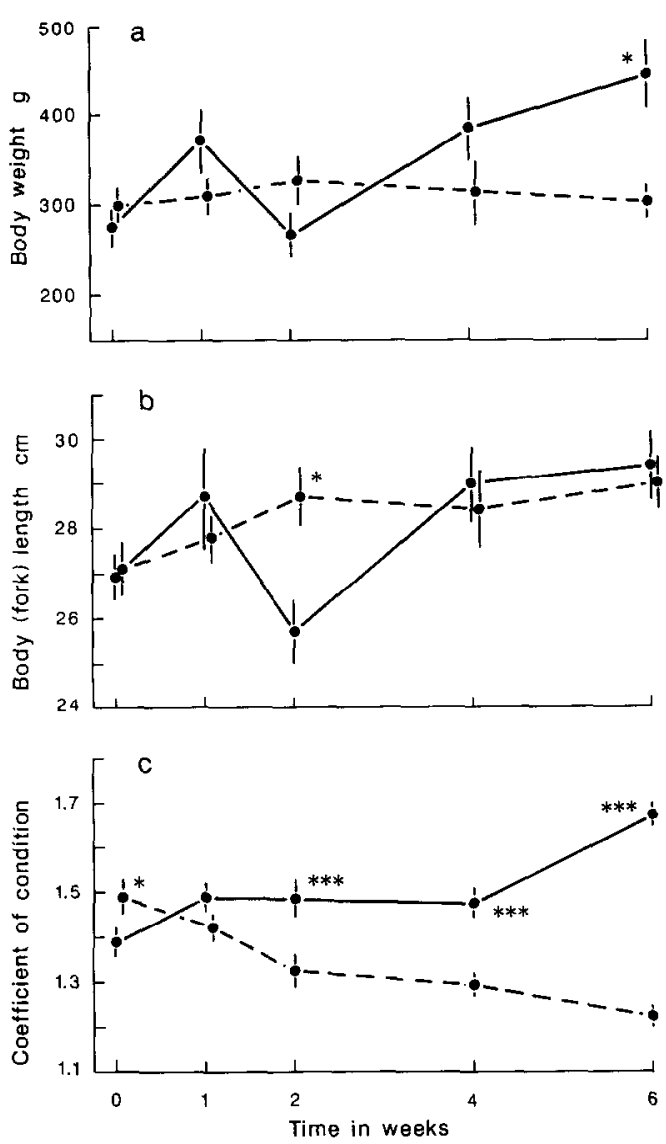

Fig. 1. Changes in (a) body weight, (b) body length, and (c) coefficient of condition of $1+$ rainbow trout during 6 weeks of starvation. Broken lines represent the starved fish, continuous lines the fed, control fish. Each point is the mean \pm SEM $(n=20)$. Asterisks denote significant differences between fed and starved fish at each sampling time $\left({ }^{*} P<0.05,{ }^{* * *} P<0.001\right)$.
However, when the coefficient of condition was considered $\left(K\right.$ factor $=100 \mathrm{~W} / \mathrm{L}^{3}$, an index of fish shape which is relatively, although not totally, independent of body size), it was clear that starvation had a marked and highly significant $(P<0.001)$ suppressive effect within 2 weeks, an effect which was maintained for a further 4 weeks (Fig. 1c). Thus by the end of the experiment the mean coefficient of condition of the fed fish was 1.68 compared with 1.22 for the starved fish (i.e., the starved fish were significantly thinner $(P<0.001)$ than the fed fish).

Blood cortisol levels were not affected by the period of starvation and remained be low $1 \mathrm{ng} \mathrm{ml}^{-1}$ in both groups of fish (Fig. 2a). Inspection of the raw data for plasma
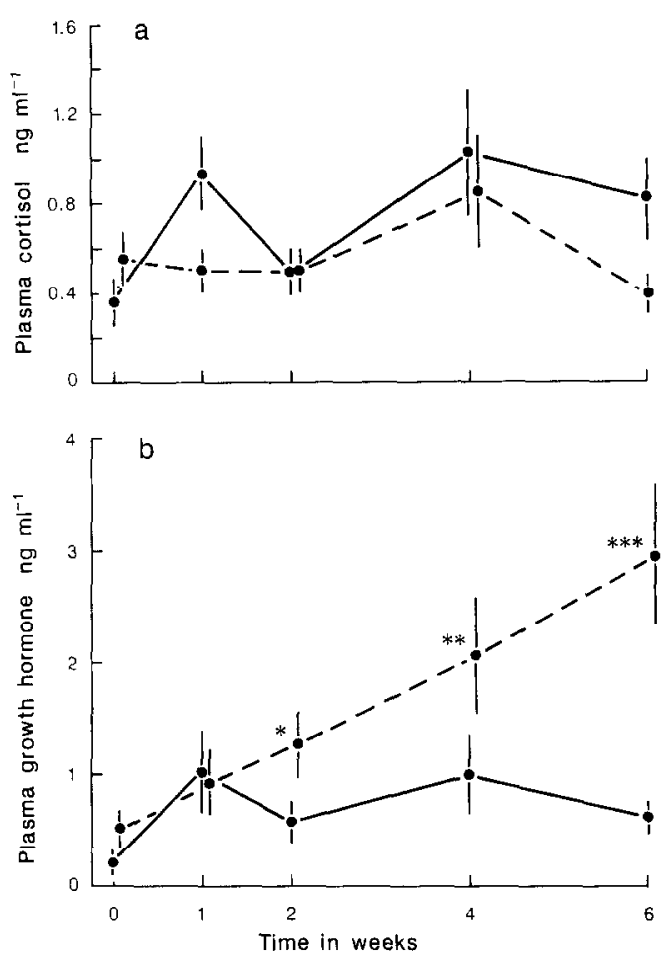

FIG. 2. Changes in (a) plasma cortisol and (b) plasma GH levels of $1+$ rainbow trout during 6 weeks of starvation. Broken lines represent the starved fish, continuous lines the fed, control fish. Each point is the mean $\pm \operatorname{SEM}(n=20)$. Asterisks denote significant differences between fed and starved fish at each sampling time $\left({ }^{*} P<0.05,{ }^{* *} P<0.01,{ }^{* * *} P<0.001\right)$. 
$\mathrm{GH}$ revealed that 7 out of the total of 560 fish had highly elevated GII levels (10-100 $\mathrm{ng} \mathrm{ml}{ }^{-1}$ compared to $0.1-10 \mathrm{ng} \mathrm{ml}^{-1}$ for the remaining 553 fish). They were also extremely small (less than $100 \mathrm{~g}$ ), and had a coefficient of condition of $<1.0$. These small, stunted fish (which were dark in appearance and had been identified as 'runts' prior to any hormone determinations) were found in both the fed and starved groups and were eliminated from the statistical analysis in an attempt to improve homogeneity of variance. Analysis of the data for the remaining fish (Fig. 2b) showed that starvation had a clear stimulatory influence on plasma $\mathrm{GH}$ levels so that by the end of the experiment $\mathrm{GH}$ levels had increased from about $0.5 \mathrm{ng} \mathrm{ml}^{-1}$ to $3 \mathrm{ng} \mathrm{ml}^{-1}(P<$ $0.001)$. The fed fish showed no such increase during the course of the experiment (Fig. 2b).

Regression analysis revealed a significant $(P<0.001)$ inverse correlation between the logarithm of the growth hormone concentration and the coefficient of condition when all the fish were considered together (Fig. 3).

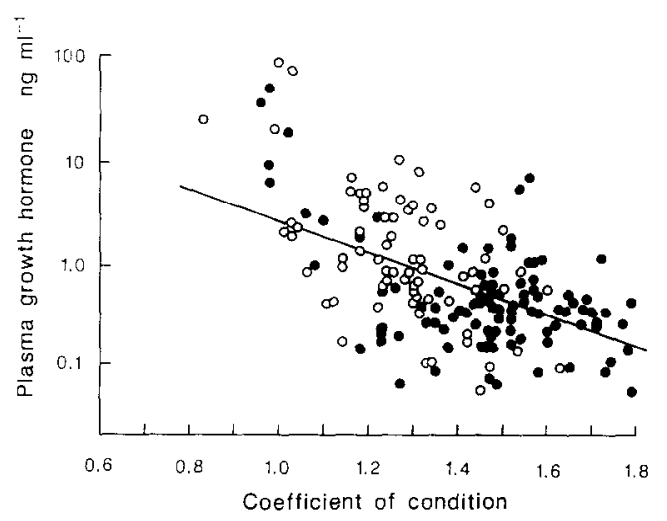

FIG. 3. Inverse correlation between the logarithm of the plasma growth hormone concentration and the coefficient of condition of $1+$ rainbow trout. Fed fish are represented by the solid circles, starved fish by the open circles. The following regression equation was obtained: $\log \mathrm{GH}=-3.65 \mathrm{KF}+4.68 ; r^{2}=25.5 \%$; $\boldsymbol{P}<0.001$.

\section{Experiment 2: The Effects of Starvation on $0+$ Rainbow Trout}

Starvation resulted in a cessation of weight increase (Fig. 4a) and a reduction in the rate of increase in length (Fig. 4b), resulting in a dramatic decrease in the coefficient of condition (Fig. 4c) in these fish.

In contrast to the results of Experiment 1 on the effect of starvation on $1+$ rainbow trout, starvation of $0+$ rainbow trout
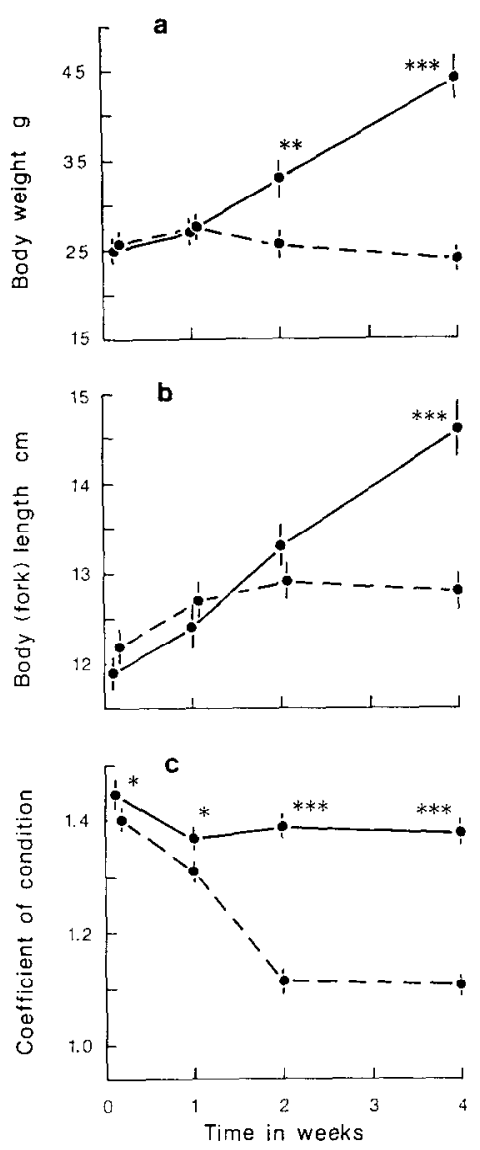

FIG. 4. Changes in (a) the body weight, (b) the body length, and (c) the coefficient of condition of $0+$ rainbow trout during 4 weeks of starvation. Broken lines represent the starved fish, continuous lines the fed, control fish. Each point is the mean $\pm \operatorname{SEM}(n=24)$. Asterisks denote significant differences between fed and starved fish at each sampling time $\left({ }^{*} P<0.01\right.$, ${ }^{* * *} P<0.0001$ ). 
caused a significant elevation of plasma cortisol levels $(P<0.01)$ for at least 2 weeks after food withdrawal (Fig. 5a). However, after 4 weeks there was no significant difference between the plasma cortisol levels of the fed and starved trout. Plasma growth hormone levels of the starved fish also increased, from a mean of $1.3 \mathrm{ng} \mathrm{ml}{ }^{-1}$ to almost $8 \mathrm{ng} \mathrm{ml}^{-1}(P<$ $0.001)$, whereas in the fed fish the growth hormone level stayed at about $1 \mathrm{ng} \mathrm{\textrm {ml } ^ { - 1 }}$ (Fig. 5b).

Regression analysis revealed a significant $(P<0.001)$ inverse correlation between the logarithm of the growth hormone concentration and the coefficient of condition when all fish were considered together (Fig. 6).
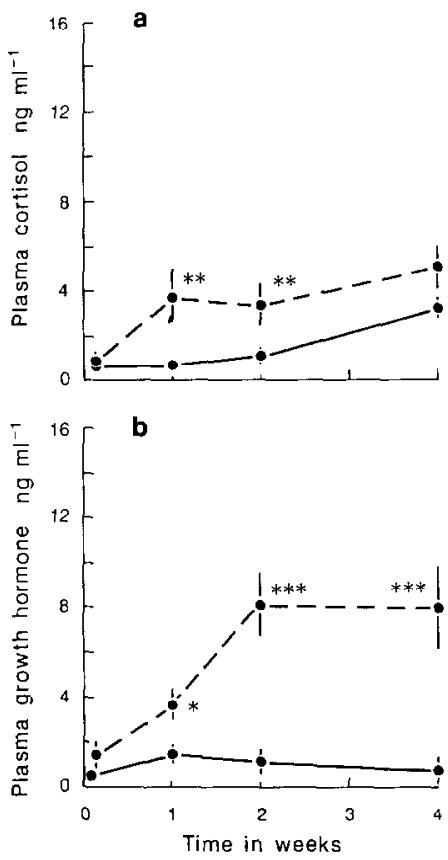

FIG. 5. Changes in (a) plasma cortisol levels and (b) plasma growth hormone levels of $0+$ rainbow trout during 4 weeks of starvation. Broken lines represent the starved fish, continuous lines the fed, control fish. Each point is the mean $\pm \operatorname{SEM}(n=24)$. Asterisks denote significant differences between fed and starved fish at each sampling time $\left({ }^{*} P<0.05,{ }^{* *} P<0.01\right.$, $* * * P<0.001)$.

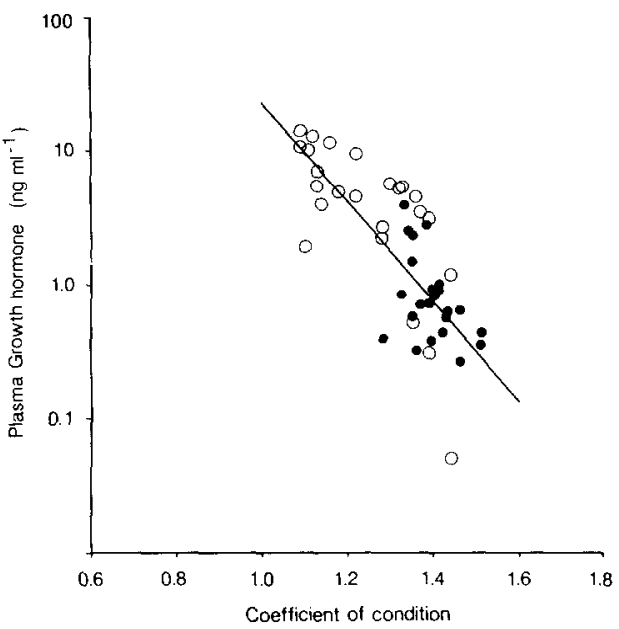

FIG. 6. Inverse correlation between the logarithm of the plasma growth hormone concentration and the coefficient of condition of $0+$ rainbow trout. Fed fish are represented by the solid circles. starved fish by the open circles. The following regression was obtained: $\log \mathrm{GH}=-8.59 \mathrm{KF}+11.7 ; r^{2}=58.8 \% ; P<0.001$.

\section{DISCUSSION}

The results of both experiments were essentially similar. In both cases, at the end of the experiment the fed fish were significantly heavier than the starved fish. However, a difference in length between fed and starved fish was apparent only in the experiment conducted with $0+$ trout. This greater effect of starvation on $0+$ fish, as compared to the $1+$ fish, may have been a consequence of the more rapid growth of $0+$ fish compared to older fish (reviewed in Weatherley and Gill, 1987). In both experiments, however, changes in the coefficient of condition provided the clearest indication of the effect of starvation. Within 1 week of beginning the experiment on $0+$ fish, and within 2 weeks in the experiment on $1+$ fish, the starved fish showed a significant loss of condition, which continued to decrease with prolonged starvation.

The effects of starvation on the plasma cortisol level differed somewhat between the two experiments. In the experiment conducted with $1+$ fish, plasma cortisol 
levels remained very low, in both the starved and fed groups, throughout the course of experiment; that is, starvation had no effect on the plasma cortisol level. In the other experiment, conducted with $0+$ fish, the starved fish had significantly higher cortisol levels, compared to the control fish, after 1 and 2 weeks of starvation. However, levels were not different at the end of the cxpcriment, after 4 wecks starvation, even though the starved fish had a much lower condition factor than the fed fish. This cortisol response during the initial period of starvation was not very pronounced when compared to the cortisol level found after trout are subjected to environmental stress; levels in starved fish were around $4 \mathrm{ng} \mathrm{ml}^{-1}$ throughout the experiment, whereas they can reach values of $100 \mathrm{ng} \mathrm{ml}^{-1}$ or more after exposure to a wide variety of different stresses (reviewed in Pickering, 1989). Taken overall, it seems unlikely that the pronounced metabolic consequences of starvation (reviewed in Love, 1980; Weatherley and Gill, 1987) could be duc to any significant cxtent to the small, or nonexistent, elevation in plasma cortisol level we observed.

In contrast to the equivocal effect of starvation on plasma cortisol levels, there was a pronounced elevation in plasma growth hormone level in the starved, but not the fed, fish in both experiments. Paradoxically this meant that the fed fish had low levels of growth hormone, yet grew steadily throughout the experiments, whereas the starved fish had elevated growth hormone levels, but did not grow. As there is no doubt that growth hormone does stimulate growth of fish under the appropriate conditions (reviewed in Donaldson et al., 1979), these results must mean that the normal growth-promoting action of growth hormone was somehow negated in starved fish. The two most likely mechanisms would seem to be down-regulation of growth hormone receptors on target tissues, or a reduction in plasma insulin-like growth factor (IGF) levels, in starved fish. There is limited evidence, obtained from "stunted" juvenile salmon maintained in seawater, that liver, gill, and kidney growth hormone receptor numbers are decreased in these fish which have elevated plasma growth hormone levels (Bolton et al., 1987 and references therein). Evidence for the second hypothesis rests on the fact that growth hormone docs not act directly on most tissues, but instead acts indirectly through IGFs (reviewed by Baxter, 1988). Although the evidence for even the existence of IGFs in fish is scant at present (Drakenberg et al., 1989; Funkenstein et al., 1989), it seems likely that they will play a similar role in fish to that in higher vertebrates. In starved mammals growth hormone level can be elevated, but IGF levels suppressed, resulting in retardation of growth (Clemmons and Van Wyk, 1987); such a situation may occur also in starved fish. The growth hormone elevation probably results from the loss of negative feedback by IGF-I (Brazeau et al., 1982).

Other authors have also investigated the effects of starvation on plasma growth hormone levels in fish, but limited information on both experimental design and analysis of the results has prevented any coherent picture emerging. McKeown and colleagues have reported the results of two experiments designed to assess the effects of starvation on plasma growth hormone levels in trout (Wagner and McKeown, 1986; Barrett and Mckeown, 1988). In both cases a highly significant elevation was observed in starved fish, the magnitude of which was similar to our results (nine and sevenfold in their two studies; sixfold in both of our experiments). However, although the results of Mckeown superficially appear similar to ours, there is a major difference in that the growth hormone levels in fed fish in our experiments were around $1 \mathrm{ng} \mathrm{ml}^{-1}$, whereas McKeown reported levels of 85.5 $\mathrm{ng} \mathrm{ml}{ }^{-1}$ (Wagner and McKeown, 1986) and $6.4 \mathrm{ng} \mathrm{ml}^{-1}$ (Barrett and McKeown, 1988) 
in fed trout. Two possible reasons for this difference in "basal" growth hormone levels in trout in good condition are discussed in detail in an accompanying paper (Le Bail et al., 1991). In contrast to these findings, Kishida and Hirano (1988) did not find any difference in plasma growth hormone levels between fed and starved eels. Although the homologous growth hormone RIA they employed was quite sensitive, most fed and starved eels had undetectable plasma growth hormone levels. However, they provided no information on the weights of their fish, and hence it is not possible to assess whether the starvation was prolonged enough to affect the condition of the fish. Our results, showing elevated growth hormone levels are a consequence of starvation, are very similar to those reported in birds and mammals. For example, dietary insufficiency, whether of carbohydrate, protein, or simply quantity, leads to elevated plasma growth hormone levels in chickens, although growth rate is, of course, depressed (Lauterio and Scanes, $1987 \mathrm{a}, \mathrm{b})$.

Our realization that the few "runts" in our experiments had the highest plasma growth hormone levels (see Results) led us to examine more closely the relationship between the condition of the fish and their plasma growth hormone level. As we show, there was an extremely significant negative correlation. We have also consistently observed such a relationship in sexually maturing trout, especially in males, which lose condition during the breeding season (Sumpter et al., 1991). This previously unreported relationship, which accounted for a large part of the variability in our plasma growth hormone levels, may explain some of the results reported by others. For example, it now seems likely that the very high growth hormone levels in "stunted" salmon which fail to acclimate successfully to seawater at the time of smoltification (Bolton et al., 1987; Björnsson et al., 1988) could be a consequence of their poor con- dition (they cease feeding upon transfer to seawater), rather than to a direct consequence of a failure to smoltify. The high plasma growth hormone levels reported in mature salmon close to spawning (Bolton $e t$ al., 1986; Le Bail et al., 1991) may also have more to do with the fish not feeding at this time than anything to do with reproduction per se. In this regard, it is interesting to note that when salmonids are injected with growth hormone, not only do they grow faster, but concomitantly their condition factor falls (Gill et al., 1985).

Although we have not investigated directly the role of growth hormone during starvation, it seems likely that it is involved in the altered metabolic processes that occur during food deprivation. In birds and mammals, growth hormone can be lipolytic; that is, growth hormone mobilizes fatty acids from adipose tissue, so that these can serve as an energy source (Campbell and Scanes, 1985; Davidson, 1987). In fish this also appears to be true (Mckeown et al., 1975; Sheridan, 1986, 1988). The earliest response to starvation is catabolism of non essential proteins for energy (Loughna and Goldspink, 1984). After this early stage of starvation, body proteins are conserved and lipid reserves are mobilized (reviewed by Love, 1980; Weatherley and Gill, 1987). Our results on the changes in plasma growth hormone levels during starvation fit well with the presumptive lipolytic role of growth hormone during starvation; it seems likely that the role of growth hormone during starvation is to help mobilise free fatty acids and glycerol. However, other hormones may also be involved in this action, such as thyroxine, cortisol, and prolactin (and probably other hormones as well, such as the catecholamines), because all of these can be lipolytic in certain circumstances (Sheridan, 1986).

In summary, nutritional status plays a major role in determining plasma growth hormone levels. Nutritional insufficiency leads to elevated growth hormone levels, 
even though growth is retarded. Care should be exercised when analyzing data on plasma growth hormone levels which have been measured for other reasons (such as assessing its role in growth, reproduction, or osmoregulation) to ensure that differences in condition between groups of fish have not had a significant impact on the results.

\section{ACKNOWLEDGMENTS}

The authors thank Miss K. M. Atkinson and Miss J. M. Fletcher (IFE) for care and maintenance of the fish, Mrs. M. A. Hurley (IFE) for statistical advice. Mr. T. I. Furnass (IFE) for some of the artwork, and SERC and MAFF for financial support.

\section{REFERENCES}

Barrett, B. A., and Mckeown, B. A. (1988). Sustained exercise augments longterm starvation increases in plasma growth hormone in the steelhead trout, Salmo gairdneri. Can. J. Zool. 66, 853-855.

Baxter, R. C. (1988). The insulin-like growth factors and their binding proteins. Comp. Biochem. Physiol. B91, 229-235.

Björnsson, B. Th., Ogasawara, T., Hirano, T., Bolton, J. P., and Bern, H. A. (1988). Elevated growth hormone levels in stunted Atlantic salmon, Salmo salar. Aquaculture 73, 275-281.

Bolton, J. P., Takahashi, A., Kawauchi, H., Kubota, J., and Hirano, T. (1986). Development and validation of salmon growth hormone radioimmunoassay. Gen. Comp. Endocrinol. 62, 230-238.

Bolton. J. P., Young, G., Nishioka, R. S., Hirano, T., and Bern, H. A. (1987). Plasma growth hormone levels in normal and stunted yearling coho salmon, Oncorhynchus kisutch. J. Exp. Zool. 242, $379-382$

Brazeau, P., Guillemin, R., Ling. N., Van Wyk, J., and Humbel, R. (1982). Inhibition par les somatomedines de la secretion de $I$ hormone de croissance stimulee par le facteur hypothalamique somatocrinine (GRF) on le peptide de synthese hp GRF. C.R. Acad. Sci. Series III, 651-655.

Campbell, R. M., and Scanes, C. G. (1985). Lipolytic activity of purified pituitary and bacteriallyderived growth hormone on chicken adipose tissue in vitro. Proc. Soc. Exp. Biol. Med. 180, 513517.

Clemmons, D. R., and Van Wyk, J. J. (1987). Factors controlling blood concentration of somatomedin C. J. Clin. Endocrinol. Metab. 13, 113-143.
Davidson, M. B. (1987). Effect of growth hormone on carbohydrate and lipid metabolism. Fndocrine Rev. 8, 115-131.

Donaldson, E. M., Fagerlund, U. H. M., Higgs, D. A., and McBride, J. R. (1979). Hormonal enhancement of growth in fish. In "Fish Physiology: Bioenergetics and Growth" (W. S. Hoar, D. J. Randall, and J. R. Brett, Eds.), Vol. 8, pp. 455597. Academic Press, New York/London.

Drakenberg, K., Sara, V. R., Lindahl, K. I., and Kewish, B. (1989). The study of insulin-like growth factors in Tilapia, Oreochromus mossambicus. Gen. Comp. Endocrinol. 74, 173-180.

Funkenstein, B., Silbergeld, A., Cavari, B., and Laron, Z. (1989). Growth hormone increases plasma levels of insulin-like growth factor (IGF-I) in a teleost, the gilthead seabream (Sparus aurata). J. Endocrinol. 120, R19-R21.

Gill, J. A., Sumpter, J. P., Donaldson, E. M., Dye, H. M., Souza, L., Berg, T.. Wypych, J., and Langley, K. (1985). Recombinant chicken and bovine growth hormones accelerate growth in aquacultured juvenile Pacific salmon, Oncorhynchus kisutch. Bio/Technology 3, 643-646.

Higgs, D. A., and Eales, J. G. (1978). Radiothyroxine kinetics in yearling brook trout, Salvelius fontinalis (Mitchill), on different levels of dietary intake. Can. J. Zool. 56, 80-85.

Ince, B. W., and Thorpe, A. (1976). The effects of starvation and force-feeding on the metabolism of the northern pike. Esox lucius L. J. Fish Biol. 8, 79-88.

Kishida, M., and Hirano, T. (1988). Development of radioimmunoassay for eel growth hormone. Nippon Suisan Gakkaishi 54, 1321-1327.

Lauterio, T. J., and Scanes, C. G. (1987a). Time course of changes in plasma concentrations of the growth hormones during protein restriction in the domestic fowl (Gallus domesticus). Proc. Soc. Exp. Biol. Med. 185, 420-426.

Lauterio, T. J., and Scanes, C. G. (1987b). Hormonal responses to protein restriction in two strains of chickens with different growth characteristics. $J$. Nutrition 117, 758-765.

Le Bail, P. Y., Sumpter, J. P., Carragher, J. F., Mourot, B., Niu, P. D., and Weil, C. (1991). Development and validation of a highly sensitive radioimmunoassay to chinook salmon (Oncorhynchus tshawytscha) growth hormone. Gen. Comp. Endocrinol. 82.

Loughna, P. T., and Goldspink, G. (1984). The effects of starvation upon protein turnover in red and white myotomal muscle of rainbow trout, Salmo gairdneri Richardson. J. Fish Biol. 25, 223-230.

Love, R. M. (1980). "The Chemical Biology of Fishes," Vol. 2. Academic Press, New York/ London. 
Mckeown, B. A., Leatherland, J. F., and Johns, T. M. (1975). The effect of growth hormone and prolactin on the mobilization of free fatty acids and glucose in the Kokanee salmon, Oncorhynchus nerka. Comp. Biochem. Physiol. B50, 425430.

Pickering, A. D., Pottinger, T. G., and Sumpter, J. P. (1987). On the use of dexamethasone to block the pituitary-interrenal axis in the brown trout, Salmo trutta L. Gen. Comp. Endocrinol. 65, 346353.

Pickering, A. D. (1989). Environmental stress and the survival of brown trout. Salmo trutta. Freshwater Biol. 21, 47-55.

Plisetskaya, E. (1985). Some aspects of hormonal regulation of metabolism in agnathans. In "Evolutionary Biology of Primitive Fishes" (R. E. Foreman, A. Gorbman, J. M. Dodd, and R. Olsson, Eds.), pp. 339-361. Plenum, New York.

Plisetskaya, E., Ottolenghi, C., Sheridan, M. A., Mommsen, T. P., and Gorbman, A. (1989). Metabolic effects of salmon glucagon and glucagonlike peptide in coho and chinook salmon. Gen. Comp. Endocrinol. 73, 205-216.
Sheridan, M. A. (1986). Effects of thyroxine, cortisol, growth hormone, and prolactin on lipid metabolism of coho salmon, Oncorhynchus kisutch, during smoltification. Gen. Comp. Endocrinol. 64, 220-238.

Sheridan, M. A. (1988). Lipid dynamics in fish: Aspects of absorption, transportation, deposition and mobilization. Comp. Biochem. Physiol. B90, 679-690.

Sumpter, J. P., Lincoln, R. F., Bye, V., Carragher, J. F., and Le Bail, P. Y. (1991). Plasma growth hormone levels during sexual maturation in diploid and triploid rainbow trout, Oncorhynchus mykiss. Gen. Comp. Endocrinol. 82.

Wagner, G. F., and McKeown, B. A. (1986). Development of a salmon growth hormone radioimmunoassay. Gen. Comp. Endocrinol. 62, 452-458.

Weatherley, A. H., and Gill, H. S. (1981). Recovery growth following periods of restricted rations and starvation in rainbow trout, Salmo gairdneri Richardson. J. Fish Biol. 18, 195-208.

Weatherley, A. H., and Gill, H. S. (1987). "The Biology of Fish Growth." Academic Press, New York/London. 